\title{
THE TWO JOURNEYS OF DIANNE WESTMACOTT
}

\author{
Peter Read
}

Nobody knew for sure just who Dianne's parents were. They knew only that in July 1946 $\mathrm{Mr}$ and Mrs Westmacott had gone to Wagga for a couple of days and come back with a threeweek-old baby. She had black hair and olive skin. To the cousins and rural workers of the property it was pretty clear that Dianne wasn't Anglo-Saxon. But what was she? Some speculated Negro; others maintained, in the local vernacular, that 'she had wog in her'. It was even whispered that it might be even worse: poor little Dianne might be 'dark'. Everyone had their theories - except Dianne. She didn't even know that she was adopted. ${ }^{1}$

In the 1940s the New South Wales Department of Child Welfare gave no suggestions that substitute parents should tell their children that they were adopted. ${ }^{2}$ Nevertheless it was an unusual adopted child that did not have a suspicion that there was something a little odd in its relations with its parents. So with Dianne. She wondered why her mother had not been discharged from the hospital at the same time as she, and why she was told always to pin her hair back 'because you look dark'. During a card game she heard her uncle say to the others that he hoped that Dianne's 'bad blood wouldn't come out' as she grew older. When she was about nine she overheard an aunt ask another aunt, 'Doesn't Dianne know who she is?' In response to her question Dianne was told, 'Don't you know? Your father was a Negro'. For an adult that would have been proof enough, but for a nine-year-old it caused only anxiety and confusion. What could it mean?

No one would elaborate and she was too frightened to inquire further. Nor did she realise the significance of other children seeing her as different. 'I was always being called blackgin when I was a kid. I've always remembered fighting over me colour.'

Peter Read recently published A hundred years war: the Wiradjuri people and the state (ANU Press). He worked for some years in Link-Up (NSW) Aboriginal Corporation and is co-editing (with Coral Edwards) The yearning of my soul: accounts of journeys to Aboriginal identity, and writing a biography of Charles Perkins.

1 This article is based on the case history of Dianne Westmacott, who in 1983 approached the Aboriginal organisation Link-Up for assistance in finding her family and identity. The information is drawn from the file and from a recorded conversation with Ms Westmacott (Sydney, February 1987). I am grateful to Dr Richard Barwick, Ms Westmacott and the co-ordinator of Link-Up, Coral Edwards, for permission to reproduce the material. To protect the identity of both the adoptive and natural families, surnames have been changed or omitted. At the time of these events, the writer was employed as a co-worker of Link-Up.

2 Until 1969, two New South Wales State Government authorities were charged with the care and protection of Aboriginal children: the Aborigines Welfare Board and the Department of Child Welfare. Children who were sent to the Aboriginal homes at Cootamundra and Kinchela were in the care of the Board; most others fell under the jurisdiction of the Child Welfare Department, which also handled all adoptions.

Instructions that adopted children should be told of their status were not given until the mid 1970s, but parents were at no time advised to tell their children that they of Aboriginal descent. Since 1982 it has been departmental policy to place Aboriginal wards with Aboriginal foster parents. 
When she was ten Dianne's mother became ill from a heart complaint. The family left the Parkes property and went to live in the Sydney suburb of Granville. Steadily her condition worsened. She promised Dianne that one day she intended to return to Parkes to die: Dianne felt that she wanted, in her last days, to tell her something important. She was denied the chance. After a long illness Mrs Westmacott died leaving Dianne, now fourteen, in the care of her father, with whom she had never enjoyed good relations. Dianne recalled that after her mother's death she had heard stories of him telling people in Sydney that he was tired of living with an old crock. He told Dianne that if she had been sixteen, she would have been thrown out of the house. As it was, he said, she would have to stay home and look after him.

[When mum died] my godmother came down from Parkes to get me, and said, 'I'll take her and bring her up' and all this, and Dad said, 'No, she's gotta stay and look after the house', and 'there'll be no one to look after me', and all this sorta garbage. But when Dad used to go to work I'd bring my friends in who were wagging school: He said I was uncontrollable and not looking after him properly. He went away to Parkes with this girl and I said, 'I'm coming too', and he said, 'No, you're staying to look after the house'. I was fourteen and left in the house, and in them days they were real strict, and my next-door neighbour rang up the welfare and the welfare lady came and got me. He didn't even know I was charged. I was taken off Dad and charged with being neglected and exposed to moral danger.

It was at the magistrate's hearing, from which Dianne was released back into the care of her father, that she learned for the first time that she was adopted.

He tried to disown me in court and that's when it came up. The judge said, 'You cannot disown an adopted child'. [When we were outside] I said to Dad, 'I am adopted, am I', and he said, 'Yeah, your mother's some bloody wog'. And I started getting a chip on the shoulder then. And I got uncontrollable. When I found out I was adopted I went around and terrorised Dad and threw rocks in his house and everything. I was a real bastard with a real big chip on me shoulder. And bashed up people and just got out of hand. I just was uncontrollable and hated Dad - it was just the way he said it and nothing I done suited him. You'd cook him a meal and he'd start picking at it or throw it out, and the floor wasn't polished good enough and he was bringing women home. Mum was only dead two weeks and he had a woman in the house and I asked him why he did it, he said, 'Well, if its just thrown at you, you take it', and he was just a pig ... In the end I got terrified of him and used to push cupboards up against the door. I started to get scared of him because of what the girls told me and that.

So Dianne was in court again, charged this time not with being neglected and exposed to moral danger, but with being an uncontrollable child. ${ }^{3}$ She was ordered to the Parramatta

3 Children might be removed from their parents in two ways: first by charging them with 'neglect' (in effect, with being neglected), second by charging them with 'being uncontrollable'. If the first charge was found proven, a child was likely to be declared a state ward, for foster or adoptive placement; if the second, the placement was more likely to be a reformatory. In both cases, unless adopted, a child remained in the nominal care of the Minister for Child Welfare. 
Girls Home. After three months she was transferred to a government hostel.

In the meantime l'd been raped and when they found out I was fregnant they sent me down to Myee [another hostel] and I stayed there till Debbie was born. And then Mrs Donaghue [the mother of the rapist] - they were all rich - and she come down and said she wanted the daughter, it was the first grand-daughter on the Donaghue side and all this garbage. And I was only fifteen and a half. They threatened me with [how] she could get it taken off me because she had the money, and even the Matron at Myee told me, 'Well you're better off letting that baby go, and letting it go to rich people.' And I said, No way. 'cause this is my baby', 'cause I'd lost my mother and I was going to keep her. So she tried to get Debbie and she said, 'Well, we'll take you out to Cobar with us'. And when Colin got out of jail I married him to keep Debbie. Even the priest said it was a hypocritical marriage, that I was only marrying the father $s o$ that I could keep the child. They had this threat over me that I would lose her because I was under age, all this hogwash. And he was always coming home smashing you up, he was an alcoholic and I finally left him, and I haven't seen him now for twentythree years.

Still Dianne was no nearer the truth about her origins, but it now appeared that her relatives had no better idea than her father exactly who her real parents were. Like him, they discouraged her efforts to find out. Dianne's uncle told her husband:

If I told her about it, everyone'd get hurt, and if I told her, a mob of blokes'd go through your house and smash the house up, and you. They used to say to me, 'Look, we don't know what nationality you got in you, we just know your mum came home to the property with you, that's all'. And I even used to think, 'What am I, a Mafia's daughter or something?'.

False lead followed false lead. Dianne went to Broken Hill hoping to find someone who looked like her. At Walgett an old koori heard her story and remarked that she probably had been stolen from his own tribe.

In about 1965 Dianne's husband Colin hired a private detective who somehow discovered that the name of her natural mother was Catherine Violet Gibson, nee Boys. ${ }^{4}$ From her birth certificate (issued in her adopted name) Dianne knew that she had been born at the Wagga Base Hospital on 3 July 1946. With this information she visited the hospital to try to find out more about her family.

I was thirty-four when I went to Wagga Base and said, 'I want to find out some information about my parents'. He didn't know I was adopted and he said,

4 It is not clear how Colin Donahue managed to do this. Perhaps he saw the adoption order held by MI Westmacott (certificates at that time named the natural parents). The secret of natural identity is very jealously guarded by state authorities. Though some states now allow adopted adults to see their natural birth certificates at the age of eighteen, at the time of writing no decision has been made in New South Wales. Normally adoptees have to ask the Adoptions Branch for special consideration to have contact made with the natural parents. If a favourable decision is taken by the Branch, it may be more than a year before contact is made. Then, of course, it is possible that the natural parents may not want to see the child. 
'When was you born?'. I told him the dates and he said, 'Well we've had a flood and we mightn't even have the files', but lucky he found this big book. And he got intrigued and he started to tell the story [of a baby named as Gibson] and he said, 'It's a funny thing, there's only two babies born that day and you don't look like the Gibson baby to me because it was a little boy.' I said, 'Was there another baby?'. He said, 'You sure this was the hospital you were born in?' and I said, 'Yeah, its on my birth certificate', and then he said, 'Well there's another little baby and her name is Boys, Caroline Boys.' He said, 'It must be you because this baby had "dark skin" ', and all this. And she was put up in the nursery away from its mother and the other little baby went home with its mother... And then the superintendent of the hospital said he shouldn't have been telling me all this information because it was under the Welfare Act and all this. Then [despite this warning] I went to the Registrar's Office and it was only a young girl there and I asked for my birth certificate under the name of Caroline Boys. She was going through this big book, and as she was looking I'd already seen everything before she got to it. It had stamped across it 'Under the Welfare Act' but she didn't notice. She was looking on this page and I was looking on that page, and I'd already seen it all. And then she looked and said, 'Oh, I'm not allowed to tell you nothing.' I said, 'It doesn't matter mate, because I've just seen it all.' And it had 'father unknown'.

Dianne's trip had, in a sense, been futile. She had already known her mother's name. The records did not specify any nationality. Why had her mother allowed her child to be described as 'dark' without giving further information? Who was her father? It seemed that records could help no longer. Only her mother could provide the information denied to Dianne for thirty-five years. Five years later the combined efforts of a firm of solicitors, the Adoptions Branch of the New South Wales Department of Youth and Community Services and Jigsaw, an organisation of adopted people, had failed to bring her any nearer to the whereabouts of her mother.

It was in March 1983 that Dianne phoned Link-Up, the Aboriginal organisation established to help Aboriginal fostered or adopted adults to find their families. In the course of the conversation we asked why she thought that she might be Aboriginal. She replied that the Aboriginal counsellor at the school which her children attended had assured her, by her colouring and features, that she was.

Our experience in Link-Up has been that most of the people who imagine, through hints by welfare officials or family members, that they may be Aboriginal, are in fact of Aboriginal descent. It was on this basis that we suggested that she write to the Adoptions Branch again to ascertain if all the information she knew about herself was correct. The reply, which closely followed the departmental guidelines about the release of 'non-identifying information' to adoptees, merely confirmed what Dianne already knew. She wrote to Link-Up:

I got a letter from Youth and Community Services but I already know all the little parts they wrote me. They said her first names, not the surname, made out that's all they knew but you could tell they must have seen a file to give me what they said ... The only thing I didn't know was that she lived, the last they heard, on the Riverina. So maybe if I look for her in the area. Her surname is Boys I think I told you anyway well thank you again. . . 
Like the other agencies, Link-Up could make no progress in finding Dianne's natural mother until it had more biographical information. After several months we discovered that Catherine Violet Boys had been born in Melbourne. Link-Up wrote to Dianne:

We learned this morning that mum, Violet Gibson (as she's known at Adoptions) and Violet Boys (as she's known at Births Deaths and Marriages) was born in Melbourne. If she was 26 at the time of your birth and you were born in 1946, that means that she was born in 1920 .

This means there is a chance that we might be able to get hold of her Birth Certificate, if you'd like us to do that. We haven't been able to find out much about your dad. as yet, but that can come later if you'd like that. In the meantime, if you'd like to try for information about your mum, could you sign this form [requesting the Certificate] and we'll send it on to Melbourne ...

The Certificate was returned to Link-Up. We wrote to Dianne:

... the important news is on your mother's side, we think. It says, as you'll see, that your mother's mother was Gladys Ann, nee - - , born at Echuca. Echuca is where the big Cumeroogunga mission nation was (and still is) and ... is one of the well-known families from there. We can't be certain yet, but it looks as though you could be related to the ... of Cumeroogunga ...

Could you let us know what your feelings are now, and what you'd like us to do. Ring us up if you'd like to, and reverse the charges...

Dianne replied:

... Yes, could you go on with every thing you both have got a lot of information, that's for sure. I hope soon we will meet someone that knows my five brothers and sisters, seeing I was the 6th child.

P.S. Where is Cumeroogunga?

If my mother was alive she must be 65 .

Diane Barwick was a person Link-Up often turned to when help was needed in tracing Victorian Aboriginal families. We wrote to her enclosing the birth certificate of Dianne's mother, asking if the information corresponded to any of the genealogies which she had compiled. She replied not with a letter but a parcel. It contained a copy of Scarlett Epstein and David Penny's Opportunity and response, which included her history of Cumeroogunga. ${ }^{5}$ There were photographs of family members, genealogies and a photocopied article about a distinguished forebear she had written for the Australian Dictionary of National Biography. With the package came a long excited letter explaining, in short, that it was time for Dianne Westmacott to come home.

She was related, it seemed, to two families who ultimately trace their ancestry to Old Maria, born in 1815, a member of the Wolligatha clan of the Pangerang tribe, whose language was known as Yotta Yotta or Yorta Yorta. What was more, her relatives would welcome her with open arms and loving hearts. 'Your client. wrote Barwick, 'would be welcome in the homes of any member of the Victorian Aboriginal community.' The letter ended with a moving paragraph. She did not, of course, intend that it should ever be published, but it stands nevertheless as a moving tribute to her contribution to the continuing cause of Aboriginal pride and self-identity: 
I hope this will be of some help. You and Coral [Edwards] are doing a job that William Cooper [the famous Victorian activist] would have approved: bringing home the children so cruelly taken away. He fought it all his life, and his kinsmen have continued - on a national basis - to take pride in their Aboriginal ancestry and help others to understand the importance of the Aboriginal heritage. I am confident that your client will be gladly welcomed by a host of relatives if Link-Up can help him/her 'go home'. They have never stopped grieving for the children lost to their community.

\section{All good wishes}

Diane

The first journey of Dianne Westmacott, to find her identity and her people, was almost at an end. She knew now that she was a direct descendant of a famous Victorian family who, through six generations, trace their ancestry to pre-invasion times.

Link-Up's next step, after consultation with Dianne Westmacott, was to travel to Melbourne. We learned the address of one of Dianne's oldest and closest relatives, her great-aunt, who lived in a Melbourne nursing home. Following our usual practice we proceeded cautiously at the meeting: no one could know in advance what old memories might be revived at the mention of Dianne, nor whether her birth had been known about at all. There was no problem. It turned out that Dianne's great-aunt was living at the time with her mother: she knew about the baby and how Dianne's adoption had been arranged. Photos were exchanged and in November 1984 Link-Up wrote to Dianne:

We have some good news for you, as we have just been to Melbourne to find out some more about your family. After asking about a bit, we went to see Mrs - . - - , who is your great-aunt. She is a lovely old lady, about 77 , who lives in a nursing home in -.., Melbourne. She knew a lot about your mum, and another sister ... What's more, she'd love to see you some time if you can get to Melbourne, and is only sorry that she can't have you to stay, but being in a nursing home, its not possible.

So what we'll do now, as soor as possible, we'll go and see your mum with your photo, and explain what's happened so far. Then we'll get back to you and bring you up to date, and if all goes well, we might be able to introduce you to her...

There was plenty that might not go well, for the initial contact with natural mothers (or children if it is the parents who approach Link-Up) is the most difficult task of all. Almost all natural mothers remarry. Frequently they do not tell their husbands, or later children, about the adopted child. No one can be contacted in advance to test the waters, for neither the sisters nor closest friends of adopting mothers can be assumed to know about the birth of an adopted child. Link-Up's policy is to approach the natural mother at the time when she is most likely to be alone, but if she is not, to ensure that the conversation takes place in private.

It was at about $2.30 \mathrm{pm}$, in early December 1984 , that we approached Catherine Violet Anderson, née Boys, at her Sydney home to inquire about her adopted daughter. When we asked for her by that name she guessed - like most adopting mothers - what we had come about. She came out onto the veranda so her husband, watching television inside, could not hear. Yes, she was Dianne's mother. Yes, she would like to see her photograph. Yes, she would like to meet her, and had been thinking about her a lot recently following some publicity about adoptions in a magazine. But no, she had not told her husband nor any of 
her other four children about their adopted sister. The first meeting would have to be in secret, but, so as not to arouse the suspicions of her husband, it must be at a place where Catherine normally might be found. He and the children would be told after she had met Dianne.

Before the meeting we again visited Dianne to explain that the whole of a future relationship can depend on the first crucial few hours. It was good to take along a photo album, to talk about the children and the recent past, but not to dwell on childhood unless asked. Above all, we urged her to avoid, for her mother's sake, those vital questions which had gnawed at her for so long: why was she adopted, and who was her father? It was better to wait to be told without asking, though this might take hours, weeks, even years.

The meeting was to take place at a cafe at the Westfield Centre, Parramatta, at 11 am on 14 December. At 10.30 we picked up Mrs Anderson at the end of her street, as she had suggested, so her husband would not see the car. She waited in the cafe while we went to meet Dianne at Parramatta Station. We walked to the cafe, introduced them to each other, and left. A week later Dianne wrote to Link-Up:

... Anyway all went well I let her do the talking 11.30 right through to 4.30 , boy I know where I get my talking from. We met again at my place the following Thursday, she gave me a jewel box she got me at 18 years. She is a nice lady but I still feel just a friend I don't feel like her daughter but I guess that's natural. So she wants to meet a lot, but she is always telling me about the whole family all the time, she is wanting to meet my mob, she said she will try to come to Linda's 21 st so she will meet the whole family my Linda looks a lot like her...

Many people are worried at first that they seem no more than friends to the parents they have just met for the first time. But for Dianne, the two years after they met brought no improvement. In 1987 she still felt outside the family circle. She had met few other relatives, her mother had still not acknowledged her publicly, she had not met her great-aunt, and her Aboriginality was regarded by her mother as something best forgotten.

[At the first meeting] she said she would've known me anywhere in the street. We sat down and had a cup of tea. She said she went to Wagga looking for me when I was fifteen, 'cause she'd know me anywhere in the street, but she never found me. She always thought I was well looked after, but then she got onto her family. She keeps getting off 'em and onto her other [Anderson] family. And I didn't want to put too much on her at first, 'cause I might've frightened her away, and I just said, 'Where's my real father?' and she said he died of a heart attack and she explained she was with this other bloke.

[Q: Did she explain how you came to be adopted?]

She'd left the first two children with the grandmother and she went with this bloke and fell pregnant, and then the bloke turned out to be married from somewhere, so she said she wasn't getting rid of me until she was in the hospital and the matron said these people are wealthy and they can't have any kids and they would like to adopt the baby. She didn't sign the papers till five years later, but she let the matron take me up to the nursery and she never seen me again, she only seen me the first time. She couldn't drag me from pub to pub because she was cleaning pubs and stuff. And then she came down to Sydney and met Mr Anderson and she got married and had two other kids to him. She kept me a big secret. All the four are together, but nobody knew about me ... She didn't 
do too much talking about the past, she was talking about general life, she just kept jumping away from it all the time. Even now I've gotta ask her, and I still haven't asked her, why she called me Caroline. 'Cause she keeps getting off it, and she just doesn't seem to wanna talk about it.

[Q: Did she know that you knew that you were Aboriginal?]

Yes, I showed her the pictures of the ancestors that you gave me, and they're really black. She goes, 'Where did you get these from?'. I said, 'Link-Up found them', and I showed her the articles and that. She took photocopies of them all 'cause she said, 'That's interesting, I might start tracking down a few of my relations.' That will help her - I don't think she knows many of her people. She told me she didn't know she was Aboriginal till she was nineteen.

[Q: Have you ever met the two daughters she had to Mr Anderson?]

No, she never ever says their surname or their addresses when she's talking about them, even though she's always talking about poor Shirley this and poor Shirley that ... That dark guy Greg I was with [in 1986] said, 'I'd give her a big miss, 'cause if she was going to say anything, she'd be saying, "Why don't you come up to the club and I'll bring it out now?" Its a bit past a joke if you've gotta be sneaking round all the time.' And she didn't like him because he was black. I thought she might have had a bad experience with black people, but I don't know.

[Q: How did she come to meet him?]

I picked her up. She wanted to come to Linda's twenty-first, well Greg was living here, I was going with him for nine months. I said to her, I've just gotta fly down here and pick Greg up'... Soon as she seen him coming, she said, 'Oh, you're not going with him, are you?' I said, 'Yeah, that's my old man.' She said, 'No, I'd give him a big A', she said, 'because you'll end up in hospital with a broken jaw or something,' she said ...

[In the end] I started to get a little bit mad with her, because she's not bringing me out, not even slowly bringing me out, you know, and I have asked her was she ashamed of me, and I have asked her was she prejudiced. She reckons she's not. But she's hiding me in the closet, its nearly two years ... She's sorta going along like we're just friends, and I don't feel anything. Sometimes I feel more angry 'cause she not doing anything.

That's what was happening when I used to fight with me step-dad. That was our twenty-year feud, because he wouldn't tell me the truth. It built up inside me and I don't want it to happen again 'cause I had a real big chip on my shoulder. I start getting [the same feeling] when I'm with her.

Dianne's story, though in its way unique, is also typical of those of many other adopted Aboriginal adults. It was, and is, common for adopting parents to hide the facts of birth and racial descent, sometimes out of some psychogenetic fantasy that some day 'blood' will 'out'. Many parents do not realise how desperately their children will want to know their origins. Baffled by discrimination against their children in school, they can offer no help beyond a reassurance of their own love. Twenty years of good relationship between parent and child can be ruined by the search for natural parents, the real identity, but it is also not unusual for an adoption, as in Dianne's case, to break down completely. 
Though some reunions are spectacularly successful, many do not follow the fantasies long rehearsed in the minds of separated children. In the twenty, thirty or forty years between birth and reunion, parents remarry, or die. Families can disintegrate. Young adults who want to begin to live as Aborigines often find that the degree of Aboriginal identity in their families, (which can range from passionate involvement to offhand denial) does not match their own expectations or desires. Though Dianne didn't particularly want further counselling, follow-up work can go on for years after a first meeting. Every six months Link-Up people meet together for a weekend of talk and relaxation. It is here that some find a new Aboriginal community, a second family, but even people who have formed good relationships with their natural kin-folk are strengthened by companionship with others in similar positions. They seem to be the only ones who really understand how difficult it is to begin living an Aboriginal identity after a lifetime on the other side. For, as all the people who have found their families through Link-Up know, the reunion is the end of one journey but the start of another.

So Dianne's second journey has begun. She now identifies as a koori, and has cousins to stay. She has that satisfaction of being able to put a face on a natural parent which only those who are adopted know. Above all she has an answer to those questions which kooris ask each other when introduced: 'What's your name?' 'Where are you from?' 'Who are your people?'

Like other adopted Aborigines, Dianne probably will not arrive at the goal which hovers seldom nearer than the far horizon: how to feel completely comfortable and secure within both the immediate and distant family circle. Even if, as is her present plan, she decides to contact her great-aunt, there are months or years of awkwardness, ignorance or anxiety. The loving hearts of the Victorian kooris will need to be understanding as well as sympathetic. But it is the returning children who have to change the most. Dianne Westmacott stopped growing as an Aborigine on the day she was adopted. On the day she met her mother she was thirty-seven years younger, as an Aborigine, than her contemporaries who stayed behind in the communities. To find peace as an Aboriginal family member she has to put aside the fears, the attitudes, the memories, the ignorance; probably in modern Australian society there is no journey which requires greater courage of herself nor understanding of others.

Like hundreds of other people who in the last five years have set out in search of a family and an Aboriginal identity, Dianne Westmacott will find that each year will bring her closer to what she has been denied. There will be rewards on the way: flashes of insight, annual visits, people to stay, family secrets, a place in the albums, invitations to weddings and funerals, midnight-to-dawn conversations, unexpected phone calls, koori stickers on the kids' suitcases. Unlike the first journey, the second journey never ends. But it is the journey, not the arrival, which matters.

\section{BIBLIOGRAPHY}

Barwick, Diane E. 'Coranderrk and Cumeroogunga: pioneers and policy', in T. Scarlett Epstein and D.H. Penny (eds), Opportunity and response: case studies in economic development, pp.10-68. London, 1972. 